\title{
Detection of Protein C Activation in Humans
}

\author{
Kenneth A. Bauer, Bryon L. Kass, David L. Beeler, \\ and Robert D. Rosenberg \\ Charles A. Dana Research Institute and the Harvard-Thorndike \\ Laboratory, Department of Medicine, Beth Israel Hospital and \\ Harvard Medical School, Boston, Massachusetts 02215; \\ Department of Biology and Whitaker College, Massachusetts \\ Institute of Technology, Cambridge, Massachusetts 02139
}

bstract. We have developed a radioimmunoassay (RIA) for the dodecapeptide that is liberated from protein $\mathrm{C}$ when this zymogen is activated by thrombin bound to thrombomodulin present on the vascular endothelium. The protein $\mathrm{C}$ activation peptide (PCP) was synthesized using the solid-phase method of Merrifield. Antisera were raised in rabbits to the synthetic analogue coupled to bovine serum albumin with glutaraldehyde. The antibody population obtained was used together with a ${ }^{125}$ I-labeled tyrosinated ligand and various concentrations of unlabeled PCP to construct a double antibody RIA capable of measuring as little as $10 \mathrm{pM}$ of this component. We have established that the synthetic dodecapeptide has the same immunoreactivity as the native peptide and that the reactivity of protein $C$ is $<1 / 2,000$ that of PCP on a molar basis. The extremely low levels of peptide in normal individuals as well as the nonspecific contributions of plasma constituents to the immunoreactive signal, necessitated the develoment of a procedure by which the PCP could be reproducibly extracted from plasma and concentrated $\sim 20$-fold. This methodology permitted us to demonstrate that the plasma PCP levels in 17 normal donors averaged 6.47 $\mathrm{pM}$, and that elevations up to $180 \mathrm{pM}$ were observed in individuals with evidence of disseminated intravascular coagulation. The validity of these measurements of protein $\mathrm{C}$ activation is supported by the fact that, in both of these situations, the RIA signal migrates on

This work was presented in part at the 25th Annual Meeting of the American Society of Hematology, San Francisco, CA 1983. Address reprint requests to Dr. Bauer, Beth Israel Hospital. 1984.

Received for publication 12 April 1984 and in revised form 18 July

J. Clin. Invest.

(c) The American Society for Clinical Investigation, Inc. 0021-9738/84/12/2033/09 \$1.00

Volume 74, December 1984, 2033-2041 reverse-phase high pressure liquid chromatography in a manner identical to that of the native dodecapeptide. We have also noted that the mean PCP concentration in seven patients fully anticoagulated with warfarin averaged $2.61 \mathrm{pM}$. Our studies also show that PCP is cleared from the plasma of primates with a $t_{1 / 2}$ of $\sim 5$ min. Given that the $t_{1 / 2}$ of activated protein $C$ is estimated to be 10-15 min, the latter enzyme appears to exert its effects on the activated cofactors of the coagulation system at concentrations considerably $<1.0$ nM.

\section{Introduction}

Human protein $\mathbf{C}$ is a vitamin $\mathrm{K}$-dependent glycoprotein of molecular weight $\sim 62,000$ that circulates in plasma as an inactive zymogen at a concentration of $\sim 4 \mu \mathrm{g} / \mathrm{ml}(1,2)$. This component consists of a heavy chain and a light chain, which are joined by a single disulfide bridge (1). During the activation of human protein $\mathrm{C}$ by thrombin, an $\mathrm{Arg}_{12}-\mathrm{Leu}_{13}$ bond is cleaved at the amino-terminal end of the heavy chain of the protein, which releases a small dodecapeptide of molecular weight $\sim 1,400$ (1). The rate of activation of protein $C$ by thrombin, the only known physiological activator, is catalyzed several thousandfold by a cofactor on the surface of the vascular endothelium $(3,4)$. This receptor, termed thrombomodulin, has been isolated from rabbit lung and exhibits a molecular weight of $\sim 74,000$ (5). Thrombin complexes with thrombomodulin at a 1:1 stoichiometric ratio of enzyme to cofactor and is then able to rapidly activate protein $\mathrm{C}$ in the presence of calcium ions. Once generated, activated protein $\mathrm{C}$ functions as an inhibitor of blood coagulation by specifically cleaving and destroying Factors Va (6) and VIIIa (7). Therefore, this serine protease is able to inhibit the platelet-dependent conversion of prothrombin to thrombin via Factor $\mathrm{Xa}$ by inactivating factor VIIIa and platelet-bound Factor Va (8).

Despite significant progress in elucidating the biochemistry of the protein C-thrombomodulin mechanism, little is known about the role of this system in initiating thrombotic disease within humans. We describe the development of the first assay 
for quantitating protein $\mathrm{C}$ activation within the vascular system. This has been accomplished by devising a radioimmunoassay (RIA) for the protein C activation peptide (PCP), ${ }^{1}$ which is generated pari passu with activated protein $\mathrm{C}$. The latter assay has been used to monitor the levels of PCP in normal individuals and in patients with hyperactive coagulation mechanisms that result from a variety of pathologic conditions.

\section{Methods}

Column chromatographic materials and reagents. DEAE-Sephadex A50, Sephadex G-10, Sephadex G-25, Sepharose 4B, and dextran sulfate were obtained from Pharmacia Fine Chemicals, Piscataway, NJ. Dry hydroxylapatite, DEAE-cellulose, Bio-Gel P-2, and Bio-Gel P-4 were purchased from Bio-Rad Laboratories, Richmond, CA. SEP-PAK $\mathrm{C}_{18}$ cartridges were bought from Waters Associates, Milford, MA. Dextran sulfate was bound to cyanogen bromide activated Sepharose 4B by a modification of the method of Pepper and Prowse (9) as described by Kisiel (1). Butoxycarbonyl (Boc) amino acids and Merrifield peptide resin were obtained from Pierce Chemical Co., Rockford, IL. Heparin (Panheprin) was purchased from Abbott Laboratories, North Chicago, IL.

Proteins. Soybean trypsin inhibitor, bovine serum albumin (BSA) and ovalbumin were purchased from Sigma Chemical Co., St. Louis, MO. Human thrombin and human antithrombin were purified by techniques established in our laboratory $(10,11)$. Protein $C$ was isolated from human plasma by a five-step procedure. The first four steps were identical to those described by Kisiel (1). These included barium citrate adsorption-elution, ammonium sulfate fractionation, DEAE-Sephadex A-50 chromatography, and dextran sulfate agarose chromatography. Hydroxylapatite chromatography was substituted for preparative gel electrophoresis as the final step of our purification schema. The resultant preparations were demonstrated to be homogeneous with respect to charge by the disc gel electrophoretic procedure of Davis (12) as modified by Rosenberg et al. (13), and with respect to size by the sodium dodecyl sulfate (SDS) gel electrophoretic system of Laemmli (14). Protein concentrations were determined from the absorbance at $280 \mathrm{~nm}$. The molar extinction coefficients for human thrombin, human antithrombin, and human protein $C$ were assumed to be 16.2 (15), 6.5 (16), and 14.5 (1), respectively.

Synthesis of peptides. The dodecapeptide $\mathrm{NH}_{2}$-Asp-Thr-Glu-AspGln-Glu-Asp-Gln-Val-Asp-Pro-Arg-COOH has been synthesized in our laboratory using the solid-phase method of Merrifield (17). The $N$ alpha-tert-butoxycarbonyl $(\mathrm{Boc})$ amino acid derivatives were utilized. Boc-nitroarg was esterified to Merrifield peptide resin (polystyrene cross-linked with $1 \%(w t / w t)$ divinyl benzene) by heating equimolar amounts of the two reagents under reflux conditions in absolute ethanol containing triethylamine $(0.9 \mathrm{~mol} / \mathrm{mol}$ of amino acid). Amino acid analysis showed $0.27 \mathrm{mmol}$ arginine/g of support. Synthesis was completed by sequentially coupling Boc-amino acids to the $\mathbf{N H}_{2-}$ terminus of the peptide with dicyclohexylcarbodiimide (DCC). Side chain protection for aspartic acid was the beta-benzyl ester, and for glutamic acid, the gamma-benzyl ester. Hydroxybenzotriazole was added to glutamine residues before admixing DCC to minimize

1. Abbreviations used in this paper: DCC, dicyclohexylcarbodiimide; DIC, disseminated intravascular coagulation; FPA, fibrinopeptide A; HPLC, high performance liquid chromatography; Boc, $\mathrm{N}$-alpha-tertbutoxycarbonyl; PEG, polyethylene glycol; PCP, protein $\mathrm{C}$ activation peptide. dehydration of the carboxamide group (18). Prior to cleaving the peptide from the resin, a ligand for radiolabeling was synthesized by coupling a tyrosine residue to the $\mathrm{NH}_{2}$-terminus of a portion of the bound dodecapeptide. The peptide components were removed from the cross-linked polystyrene matrix by hydrogenation (19). After elimination of the resin and catalyst by filtration, the resultant polypeptides were purified by DEAE-cellulose chromatography and polyacrylamide P-4 gel filtration.

Appropriate quantities of purified dodecapeptide and its tyrosinated derivative were hydrolyzed in $6 \mathrm{~N} \mathrm{HCl}$ in sealed tubes at $110^{\circ} \mathrm{C}$. After removal of $\mathrm{HCl}$, the amino acid content of the hydrolysate was determined using a Durrum model D500 amino acid analyzer (Durrum Instrument Corp., Sunnyvale, CA). The synthetic dodecapeptide was also analyzed by fast atom bombardment mass spectrometry by Dr. Vernon Reinhold and Dr. Steven Carr (Harvard School of Public Health, Boston, MA) utilizing the Finnigan-MAT 312 double-focusing mass spectrometer (Finnigan-MAT, Sunnyvale, CA).

The purified polypeptide pools were quantitated by absorbance at $210 \mathrm{~nm}$. Amino acid analysis was carried out on 0.1 absorbance units of synthetic material. The amount of peptide could then be obtained by dividing the nanomole sum of amino acids present by the number of substituents comprising the peptide.

Preparation of immunogens. The dodecapeptide synthesized as outlined above was coupled to bovine serum albumin (BSA) with either carbodiimide (20) or glutaraldehyde (21). To accomplish coupling of the peptides by the first method, $7.5 \mathrm{mg}$ of synthetic PCP in $0.5 \mathrm{ml}$ of distilled water was admixed with $15 \mathrm{mg}$ of BSA in an equal volume of water. Thereafter, $0.5 \mathrm{ml}$ of carbodiimide at a concentration of 300 $\mathrm{mg} / \mathrm{ml}$ was immediately added to the above solution. After the mixture had been stirred for $1 \mathrm{~h}$ at room temperature, it was dialyzed against three changes of $4 \mathrm{~L}$ of distilled water for $16 \mathrm{~h}$. To accomplish coupling of the peptide by the second method, $4 \mathrm{mg}$ of synthetic PCP in $1 \mathrm{ml}$ of $0.1 \mathrm{M}$ potassium phosphate, $\mathrm{pH} 7.0$ was admixed with $20 \mathrm{mg}$ of BSA in the same volume of buffer. Thereafter, $1 \mathrm{ml}$ of $0.021 \mathrm{M}$ glutaraldehyde was added drop-wise to the above solution at room temperature with constant stirring. The sample was dialyzed against three changes of $4 \mathrm{~L}$ of $0.15 \mathrm{M} \mathrm{NaCl}$ in $0.02 \mathrm{M}$ sodium barbital, pH 7.0.

Antisera. The two peptide-albumin conjugates were lyophilized to dryness and then dissolved in $0.15 \mathrm{M}$ saline at a concentration of 2 $\mathrm{mg} / \mathrm{ml}$. Each was then thoroughly mixed with an equal volume of complete Freund's adjuvant and used to immunize two white New Zealand rabbits. The animals were inoculated with $0.6 \mathrm{ml}$ of the emulsion in multiple subcutaneous sites at 1-wk intervals for a total of three injections. 1 wk later, an immunization consisting of $0.4 \mathrm{ml}$ i.m. of emulsion was given in the haunches and subsequent boosters were given in the same manner at 4-wk intervals. Before administration of each booster immunization, $50 \mathrm{ml}$ of blood was collected over $2 \mathrm{~d}$ from each rabbit and pooled separately. To remove residual fibrinogen and destroy complement components, all sera were incubated for $\mathbf{4 5}$ min at $56^{\circ} \mathrm{C}$ prior to use. Specific binding of radiolabeled tyrosinated PCP by the antisera resulted after 1 mo of immunization.

Crude rabbit antisera to human protein $\mathbf{C}$ was a gift from Dr. J. Stenflo (University of Lund, Malmo, Sweden). It was heated as described above and then used without further purification. Sheep anti-rabbit IgG serum was obtained as previously outlined $(22,23)$. Goat anti-rabbit IgG was purchased from Scantibodies Laboratory, Lakeside, CA.

RIA. Radiolabeling of tyrosinated PCP was carried out by the chloramine T method of Greenwood et al. (24) using $10 \mu \mathrm{g}$ of peptide 
and $1 \mathrm{mCi}$ of carrier free $\mathrm{Na}^{125} \mathrm{I}$ (Amersham Corp., Arlington Heights, IL). After separation of the peptide from free iodide by Sephadex G10 gel filtration, $>70 \%$ of the labeled material could be bound by high concentrations of antisera directed against this component. The PCP RIA was performed using a double antibody approach. The initial reaction mixtures were composed of $50 \mu \mathrm{l}$ of radiolabeled tracer $(\sim 10,000 \mathrm{cpm}), 500 \mu \mathrm{l}$ of unlabeled peptide standards or unknown sample, as well as $100 \mu \mathrm{l}$ of the PCP antibody population. All of the reagents had been extensively diluted in Tris-buffered saline $(0.05 \mathrm{M}$ Tris- $\mathrm{HCl}, 0.10 \mathrm{M} \mathrm{NaCl}, 0.02 \%$ [wt/vol] sodium azide, $\mathrm{pH} 7.5$ containing $1 \mathrm{mg} / \mathrm{ml}$ ovalbumin). The sensitivity of the assay was maximized by diluting the crude antiserum 500-fold. Under these conditions, 33\% of the ${ }^{125}$ I-labeled counts were immunoprecipitable. To act as a carrier in the second antibody separation, $5 \%$ (vol/vol) nonimmune rabbit serum was added to the solution containing the tracer. The tubes were mixed and then incubated at $4^{\circ} \mathrm{C}$ for $18 \mathrm{~h}$. Thereafter, radiolabeled antigen bound to the antibody was separated from ${ }^{125}$ I-labeled tyrosinated peptide. This was accomplished by adding $1 \mathrm{ml}$ of $1 \%$ ( $\mathrm{vol} / \mathrm{vol})$ goat anti-rabbit IgG, 3.4\% (wt/vol) polyethylene glycol (PEG) 6000 in Tris-buffered saline to each tube. The relative amounts of nonimmune rabbit sera as well as goat anti-rabbit IgG were chosen to give the maximal precipitation of radiolabeled antigen. The tubes were centrifuged at $4^{\circ} \mathrm{C}$ for $20 \mathrm{~min}$ at $1,800 \mathrm{~g}$ and washed once at $4^{\circ} \mathrm{C}$ with Trisbuffered saline. The resultant precipitates were quantitated for ${ }^{125} \mathrm{I}$ counts.

Protein $\mathrm{C}$ was radiolabeled as described above using $5 \mu \mathrm{g}$ of antigen and $0.2 \mathrm{mCi}$ of $\mathrm{Na}^{125} \mathrm{I}$. The protein C RIA was accomplished in a manner entirely analogous to that described for the PCP RIA except that the volume of unlabeled protein $C$ standard or unknown sample was only $50 \mu \mathrm{l}$ and the diluent for all reagents was $0.155 \mathrm{M} \mathrm{NaCl}$ and $0.005 \mathrm{M}$ EDTA in $0.0225 \mathrm{M}$ sodium phosphate, $\mathrm{pH} 7.4$, with $0.2 \%$ (wt/vol) sodium azide and $3.0 \%$ (wt/vol) BSA added. The second antibody system consisted of $10 \%$ (vol/vol) sheep anti-rabbit IgG serum, 2.6\% (wt/vol) PEG 6000 in 0.0225 sodium phosphate, 0.155 $\mathrm{M} \mathrm{NaCl}, 0.005$ EDTA, pH 7.4 with $0.01 \%$ (wt/vol) sodium azide and $0.2 \%$ (wt/vol) BSA added. This assay is able to accurately detect protein $C$ zymogen down to a level of $\sim 0.05 \mathrm{nM}$. The fibrinopeptide A (FPA) RIA was performed with a kit provided by Mallinckrodt, Inc., St. Louis, MO.

Collection and processing of blood samples. Venipunctures were performed atraumatically with 19 - or 21 -gauge butterfly infusion sets using a two-syringe technique. Blood samples for RIA were drawn into plastic syringes preloaded with the appropriate solutions as described below. These included: (a) "PCP anticoagulant": citric acid $7.3 \mathrm{mg} /$ $\mathrm{ml}$, sodium citrate $22 \mathrm{mg} / \mathrm{ml}$, dextrose $24.5 \mathrm{mg} / \mathrm{ml}$, EDTA $2.234 \mathrm{mg} /$ $\mathrm{ml}$, adenosine $1.602 \mathrm{mg} / \mathrm{ml}$, and heparin $25 \mathrm{U} / \mathrm{ml}$. The ratio of anticoagulant to blood used was 0.2:1.0 (vol/vol). (b) "Protein C anticoagulant": $3.8 \%$ (wt/vol) sodium citrate; the ratio of anticoagulant to blood used was 0.1:0.9 (vol/vol). (c) "FPA anticoagulant": this preparation was provided by Mallinckrodt, Inc. The ratio of anticoagulant to blood used was 0.1:0.9 (vol/vol). After collection of blood samples, plasma fractions were obtained by centrifugation at $4^{\circ} \mathrm{C}$ for $15 \mathrm{~min}$ at $1,600 \mathrm{~g}$ and stored at $-80^{\circ} \mathrm{C}$ before use. Specimen collection and informed consent procedures were approved by the institution's human experimentation committee.

Normal ranges for PCP, protein C, and FPA were derived from data on 17 control subjects. This population consisted of healthy individuals who gave a negative history for bleeding as well as thrombosis, and were not taking any medications at the time of sample collection.
Coagulation studies. Routine coagulation studies including prothrombin time, activated partial thromboplastin time, thrombin time, and fibrinogen were performed by standard laboratory methods (25). FDPs were determined using the Thrombo-Wellcotest (Wellcome Reagents, Research Triangle Park, NC).

Analysis of data. Estimation of relative immunoreactivity, computation of the slopes of the dose-response curves, as well as determinations of the various associated indices were obtained by a leastsquares fit of the RIA results to a "four parameter" model as described by Rodbard $(26,27)$. Statistical analyses of data were conducted by standard techniques (28). In most instances, the means are provided with associated standard errors.

\section{Results}

The dodecapeptide $\mathrm{NH}_{2}$-Asp-Thr-Glu-Asp-Gln-Glu-Asp-GlnVal-Asp-Pro-Arg-COOH was synthesized using the solid-phase method of Merrifield (17). After isolation by DEAE-cellulose chromatography and polyacrylamide P-4 gel filtration, the composition of the dodecapeptide was determined by amino acid analyses. A single mole of peptide was found to contain $3.85,1.04,1.01,4.26,0.95$, and $0.90 \mathrm{~mol}$ of aspartic acid, threonine, proline, glutamic acid, valine, and arginine, respectively. The synthetic analogue thus possessed the same relative proportions of the relevant amino acids as the terminal 12 residues of the heavy chain of protein $C$. The synthetic polypeptide was also analyzed by mass spectrometry, which demonstrated an intense protonated ion peak at a molecular weight of 1,446 (data not shown) identical to that calculated from the amino acid composition. Furthermore, a series of spectra exhibited fragment ions that confirmed the primary sequence of the polypeptide for the first seven $\mathrm{NH}_{2}$-terminal residues.

The synthetic dodecapeptide was covalently linked to BSA with either carbodiimide or glutaraldehyde, and the two conjugates were used to raise antisera in rabbits against the protein $\mathrm{C}$ activation peptide. Both of these approaches were effective in generating the appropriate antibody populations. However, the PCP RIA was constructed using antiserum obtained from one of the rabbits that had been immunized for 4 mo with synthetic dodecapeptide coupled to BSA with glutaraldehyde. Fig. 1 shows a typical PCP titration curve conducted with this

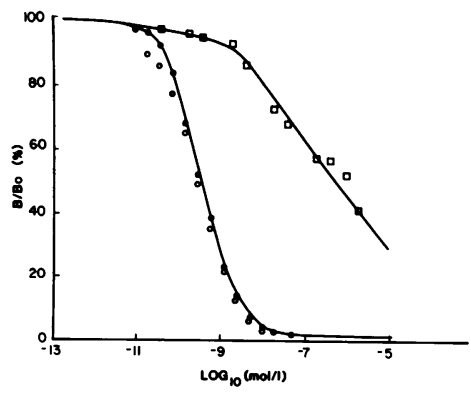

Figure 1. Inhibition of binding of ${ }^{125} \mathrm{I}$-labeled tyrosinated PCP by synthetic $P C P$, native $P C P$, and protein C. Synthetic PCP (๑), native $\mathrm{PCP}(\mathrm{O})$, and protein $C$ () were compared by RIA. The different species were added at varying molar concentrations as competing antigens. The zymogen was completely converted to activated protein $C$ and native PCP by the addition of $16 \%$ (wt/wt) thrombin with subsequent incubation at $37^{\circ} \mathrm{C}$ for $6 \mathrm{~h}$ (Fig. 2). The solvent conditions used were $0.10 \mathrm{M}$ $\mathrm{NaCl}$ in $0.05 \mathrm{M} \mathrm{Tris}-\mathrm{HCl}, \mathrm{pH} 7.5$, and $37^{\circ} \mathrm{C}$. 
antibody population. The ${ }^{125} \mathrm{I}$-labeled ligand bound to the specific antibody in the presence of a given amount of competing antigen divided by the ${ }^{125} \mathrm{I}$-labeled ligand bound to the specific antibody in the absence of competing antigen $\left(B / B_{0}\right)$ is plotted against the $\log _{10}$ of the molar amount of competing antigen. The solid lines represent a computer-generated fit of the data to the four-parameter model of Rodbard et al. (26, 27). The mean slope and midpoint of the logit-log doseresponse curves for 37 individual $\mathrm{PCP}$ assays were $-0.944 \pm 0.01$ and $0.284 \pm 0.01$, respectively. Results obtained with duplicate assays at varying concentrations of PCP demonstrate that the intraassay coefficient of variation of this method within the linear portion of the titration curve is $<4 \%$. The detection limit of the technique is $10 \mathrm{pM}$ of peptide. This level of activation fragment results in the precipitation of a greater amount of ${ }^{125}$ I-labeled peptide counts than that obtained in the absence of competing antigen minus three times its coefficient of variation.

The RIA described above was used to study the reactivity of purified human protein $\mathrm{C}$ that contains the PCP amino acid sequence as the $\mathrm{NH}_{2}$-terminus of its heavy chain. The reactivity of this zymogen was estimated by contrasting the molar concentration of this species and PCP required to displace $50 \%$ of the immunoprecipitable counts from our antibody population. In the experiment depicted in Fig. 1, the concentration of synthetic PCP needed to displace $50 \%$ of the immunoprecipitable counts is $0.375 \mathrm{nM}$ as compared with a concentration of $767 \mathrm{nM}$ for purified human protein $\mathrm{C}$. Thus, the reactivity of the protein $C$ zymogen is $<1 / 2,000$ that of the activation peptide on a molar basis. Similar data were obtained with two other preparations of human protein $\mathrm{C}$ (data not shown). Therefore, a normal plasma protein $\mathrm{C}$ level of $\sim 60 \mathrm{nM}$ might contribute as much as $3 \mathrm{pM}$ to the plasma PCP RIA signal. It should also be noted that the slope of the protein $C$ logit-log dose response curve is different from that of PCP. This suggests that either a qualitative difference exists between the immunoreactive region on the protein $C$ zymogen and the similarly designated region of $\mathrm{PCP}$, or that our antibody population has differing affinities for the two sites (29).

To determine the conditions necessary for the complete activation of human protein $\mathrm{C}$, we performed a series of experiments in which a fixed amount of purified zymogen was activated with varying quantities of human thrombin (Fig. 2). The environmental conditions were established at $0.10 \mathrm{M}$ $\mathrm{NaCl}$ in $0.05 \mathrm{M}$ Tris- $\mathrm{HCl}$, pH 7.5 and $37^{\circ} \mathrm{C}$. Aliquots were removed from the incubation mixtures at timed intervals from 0 to $6 \mathrm{~h}$, mixed with an anticoagulant consisting of antithrombin and heparin at final concentrations of $0.058 \mu \mathrm{g} / \mathrm{ml}$ and 0.303 $\mu \mathrm{g} / \mathrm{ml}$, respectively, and monitored by PCP RIA. As the ratio of thrombin to protein $\mathrm{C}$ zymogen was increased from 0.02 to 0.16 (wt/wt), a higher initial rate of peptide production was observed and the absolute molar level of activation fragment generated approached the initial zymogen concentration. A

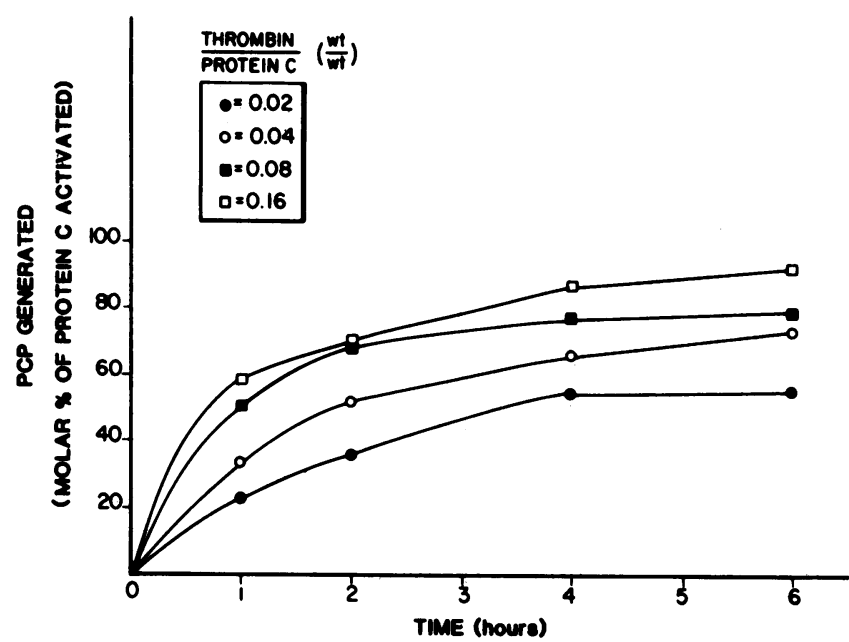

Figure 2. Time course for the activation of human protein $\mathrm{C}$ by human thrombin. Protein C activation was monitored by RIA. PCP generation was achieved by incubating the zymogen with thrombin at varying ratios of enzyme to substrate (see legend). At the appropriate time intervals, aliquots were withdrawn and transferred to a test tube containing human antithrombin and heparin at final concentrations of $0.058 \mu \mathrm{g} / \mathrm{ml}$ and $0.303 \mu \mathrm{g} / \mathrm{ml}$, respectively. The starting concentration of protein $\mathrm{C}$ was $990 \mathrm{nM}$ and the solvent conditions used were $0.10 \mathrm{M} \mathrm{NaCl}$ in $0.05 \mathrm{M}$ Tris- $\mathrm{HCl}, \mathrm{pH} 7.5$, and $37^{\circ} \mathrm{C}$.

thrombin to protein $\mathrm{C}$ ratio of 0.16 resulted in the activation of $92.3 \%$ of the zymogen after $6 \mathrm{~h}$ of incubation. These conditions of maximal protein $\mathrm{C}$ conversion were then used to establish a logit-log dose-response relationship for the native peptide. As shown in Fig. 1, this curve has a slope and midpoint that are similar to that of the synthetic analogue. Thus, these data indicate that synthetic PCP and native dodecapeptide have virtually identical immunochemical characteristics.

Despite the specificity of our RIA, several independent lines of evidence strongly suggested that plasma constituents other than protein $\mathrm{C}$ contributed to a nonspecific basal signal in the assay and that ambient levels of PCP in normal individuals were below the sensitivity of our RIA (data not shown). We concluded that it was impossible to accurately quantitate PCP levels in human plasma directly. We therefore devised a procedure by which the peptide could be extracted from plasma and concentrated $\sim 20$-fold. To this end, the larger proteins were initially precipitated by adding 0.1 vol of $7 \mathrm{M}$ perchloric acid to 1 vol of plasma. After $15 \mathrm{~min}$ of incubation in an ice bath, the samples were centrifuged at $27,000 \mathrm{~g}$ for $20 \mathrm{~min}$ at $4^{\circ} \mathrm{C}$. To salt out the residual perchlorate ions, the supernatant fluid was pipetted into a centrifuge tube and a sufficient amount of a solution of $3.5 \mathrm{M}$ potassium hydroxide was added to raise the $\mathrm{pH}>7$. After a second centrifugation, the supernatant was acidified with an amount of $10 \%$ (vol/vol) phosphoric acid sufficient to lower the $\mathrm{pH}$ of the solution to $<3$. A SEP-PAK $\mathrm{C}_{18}$ cartridge was then washed 
with $5 \mathrm{ml}$ of $80 \%$ (vol/vol) methanol followed by $5 \mathrm{ml}$ of $0.1 \%$ (vol/vol) phosphoric acid. The sample was applied to the cartridge and the matrix was washed with $4 \mathrm{ml}$ of distilled water. The peptide was subsequently eluted with $4 \mathrm{ml}$ of $80 \%$ (vol/vol) methanol into $12 \times 75 \mathrm{~mm}$ test tubes. The contents of the tubes were evaporated to dryness overnight in a Savant Speed Vac Concentrator (Savant Instruments Inc., Hicksville, NY). Samples were individually reconstituted with $1.2 \mathrm{ml}$ of $0.10 \mathrm{M} \mathrm{NaCl}$ in $0.05 \mathrm{M}$ Tris- $\mathrm{HCl}, \mathrm{pH} 7.5$ containing $0.02 \%$ (wt/vol) sodium azide and $1 \mathrm{mg} / \mathrm{ml}$ ovalbumin. The specimens were then assayed by RIA for PCP immunoreactivity.

The above extraction and concentration procedure allows the measurement of plasma PCP levels of less than $10 \mathrm{pM}$. We have attempted to quantitate the concentrations of dodecapeptide within the blood of normal individuals using this methodology. In all of the assays, we have also used a normal plasma control that had been "spiked" with 1.2 pmol of native peptide. The results obtained on 10 occasions with plasma from normal donors using optimal anticoagulant for collection of blood (see below) indicate that the uncorrected basal level of $\mathrm{PCP}$ is $3.47 \mathrm{pM} \pm 0.52$. Furthermore, we were able to recover $58.4 \% \pm 2.4$ of the added dodecapeptide. The extent of recovery appears to be independent of the amount of PCP added to the plasma (Table I), or the volume of plasma utilized in the extraction process (data not shown). This was confirmed by adding ${ }^{125} \mathrm{I}$-labeled tyrosinated peptide to plasma. Approximately $90 \%$ of the loss in radioactivity occurred during the extraction procedure prior to sample concentration on the SEP-PAK cartridge. We therefore calculate that the normal plasma peptide level is $\sim 6.19 \mathrm{pM} \pm 0.88$. We have routinely used 6-12 $\mathrm{ml}$ of plasma to assay PCP levels in normal individuals. In patients with excessive hemostatic system activity, we have used as little as $0.5 \mathrm{ml}$ to obtain accurate measurements of peptide concentration.

To demonstrate that the RIA signal obtained after the extraction and concentration procedure represents PCP, $50 \mathrm{ml}$ of plasma from a normal individual as well as a smaller volume of the same plasma spiked with native peptide were processed in the customary fashion. The samples were then reconstituted in $1 \mathrm{ml}$ of $0.1 \%$ (vol/vol) phosphoric acid and

Table I. Recovery of PCP Added to Plasma

\begin{tabular}{lll}
\hline PCP added to plasma & $\begin{array}{l}\text { PCP measured after } \\
\text { extraction and concentration }\end{array}$ & Recovery \\
\hline$p M^{*}$ & $p M \ddagger$ & $\%$ \\
9.0 & 5.51 & 61.2 \\
18.0 & 11.6 & 64.2 \\
36.0 & 23.1 & 64.2
\end{tabular}

* The corrected basal PCP level of the plasma was $5.31 \mathrm{pM}$. ¥ The results are the mean of two separate experiments. The uncorrected basal plasma PCP level has been subtracted from the data.

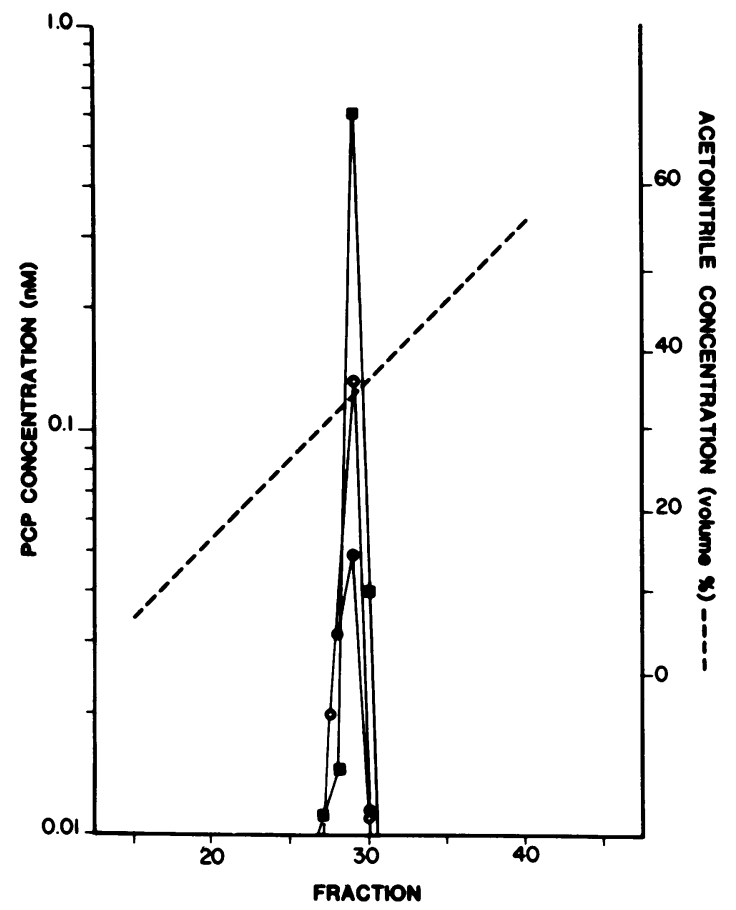

Figure 3. The elution from a Microsorb $\mathrm{C}_{18}$ HPLC column of PCP immunoreactivity from normal plasma $(\bullet)$, plasma of a patient with DIC associated with pancreatic carcinoma (0), and native PCP ( $($ ).

The column was $25 \mathrm{~cm} \times 4.6 \mathrm{~mm}$, and was equilibrated with $0.1 \%$ (vol/vol) phosphoric acid. Peptide immunoreactivity was eluted with an acetonitrile gradient in $0.1 \%$ ( $\mathrm{vol} / \mathrm{vol})$ phosphoric acid and fractions of $1.2 \mathrm{ml}$ were collected. The contents of the tubes were evaporated to dryness, redissolved in $1.2 \mathrm{ml}$ of Tris-buffered saline with $1 \mathrm{mg} / \mathrm{ml}$ ovalbumin to give a final $\mathrm{pH}$ of 7.5 , and assayed for PCP content.

injected onto a Microsorb $\mathrm{C}_{18}$ high performance liquid chromatography (HPLC) column. The flow rate was $1 \mathrm{ml} / \mathrm{min}$. The mobile phase consisted of $0.1 \%$ (vol/vol) phosphoric acid and a linear gradient of acetonitrile in $0.1 \%$ (vol/vol) phosphoric acid was applied to the column. The column effluents were monitored with the PCP RIA, which revealed that the peptide eluted in both samples at exactly the same acetonitrile concentration of $\sim 30 \%$ (vol/vol) (Fig. 3). Greater than $80 \%$ of the applied immunoreactivity could be recovered in the peak fractions. These results indicate that the PCP RIA utilized, in conjunction with appropriate sample processing techniques, is able to accurately measure plasma concentrations of the dodecapeptide.

During the quantitation of plasma PCP levels, we have insured that in vitro protein $C$ activation is completely suppressed after venipuncture. The solution utilized for this purpose is the "PCP anticoagulant" which contains ACD (citric acid, sodium citrate, dextrose), EDTA, adenosine (platelet inhibitor), and heparin $(25 \mathrm{U} / \mathrm{ml})(30)$. The efficacy of this solution was demonstrated by immediately mixing blood sam- 
ples from three normal donors with the above anticoagulant mixture. Purified human thrombin $(0.1 \mu \mathrm{g} / \mathrm{ml})$ or buffer was then added to different aliquots of each sample, and PCP immunoreactivity was subsequently quantitated. The levels of this component in aliquots to which enzyme had been added were not significantly different from those in which buffer had been admixed (5.63 pM \pm 0.46 vs. $5.64 \mathrm{pM} \pm 0.72)$.

In two further series of experiments, we have established that the PCP immunoreactivity measured by our antibody population is stable for several hours within the plasma environment and that the peptide does not distribute into the cellular element fraction of blood (data not shown).

To initiate an assessment of the sensitivity and specificity of the assay, studies have been conducted in which the extent of protein $\mathrm{C}$ activation has been analyzed by PCP RIA in normal individuals as well as in patients with altered hemostatic system activity. PCP levels in 17 normals below the age of 50 ranged between 3.79 and $13.2 \mathrm{pM}$. Nine individuals with disseminated intravascular coagulation (DIC) in association with carcinoma, acute promyelocytic leukemia, or KasabachMerritt syndrome were also studied (Table II). The DIC syndrome was identified by characteristic abnormalities of routine clinical tests such as prolonged thrombin time, diminished fibrinogen concentration, elevated fibrinogen (fibrin) split products, or reduced platelet count (31). The levels of FPA, which reflects the in vivo enzymatic activity of thrombin on fibrinogen were also measured by RIA (21). These patients exhibited PCP levels ranging from 31.8 to $177 \mathrm{pM}$. None of these individuals had recently received heparin, nor did any exhibit clinical or laboratory evidence of either renal or hepatic dysfunction at the time of sampling. Linear regression analysis of the data for PCP vs. FPA yields a line described by the equation $y=2.46 x+52.6$, with an associated correlation coefficient $(r)$ of 0.878 . We have also quantitated ambient concentrations of protein $\mathrm{C}$ in the above patient population. Similar examination of the results derived for PCP vs. the levels of this zymogen yields a $r$ value of 0.042 .

Figure 3 depicts the HPLC elution profile of peptide extracted from $6 \mathrm{ml}$ of plasma obtained from patient 4 with DIC in association with pancreatic carcinoma. The PCP immunoreactivity eluted at the same acetonitrile concentration as the native peptide and $71 \%$ of the applied signal was recovered in the peak fractions of the gradient profile. These results confirm our supposition that the RIA signal accurately reflects the levels of dodecapeptide. The data also suggest that larger $\mathrm{NH}_{2}$-terminal fragments of the heavy chain of protein $\mathrm{C}$, which could be produced during DIC by the action of proteases other than thrombin, do not contribute to the signal measured with our assay.

We have also noted significant reductions in the plasma PCP levels of patients who were chronically on warfarin anticoagulants with prothrombin times greater than $1 \frac{1}{2}$ times control (Table III). None of these seven individuals displayed evidence of congenital protein $\mathrm{C}$ deficiency and the mean level of peptide averaged $2.61 \mathrm{pM} \pm 1.03(\mathrm{SD})$ as compared to a mean of $6.47 \mathrm{pM} \pm 2.39$ (SD) in our normal population $(P$ $<0.001$ ). It thus seems likely that protein $C$ zymogen is activated, albeit at extremely low levels, under normal physiological conditions. Furthermore, clinical states known to be associated with either heightened or diminished levels of in vivo thrombin generation $(30,32)$ result in the expected elevations or reductions in the concentrations of PCP.

Table II. The Levels of PCP in Patients with Disseminated Intravascular Coagulation

\begin{tabular}{|c|c|c|c|c|c|c|c|c|c|}
\hline $\begin{array}{l}\text { Patient } \\
\text { no. }\end{array}$ & Disorder & $\begin{array}{l}\text { Thrombin } \\
\text { time }\end{array}$ & Fibrinogen & FDPs & Platelets & FPA & PCP & Protein C & \\
\hline & & & $m g / d l$ & $\mu g / m l$ & $\times 10^{3} / \mathrm{ml}$ & $n M$ & $p M$ & $n M$ & \% normal \\
\hline \multirow[t]{2}{*}{1} & Prostatic & & & & & & & & \\
\hline & carcinoma & $27.8 / 19.6$ & 190 & 160 & 43 & 5.90 & 58.2 & 35.9 & 63 \\
\hline \multirow[t]{2}{*}{2} & Prostatic & & & & & & & & \\
\hline & carcinoma & $19.4 / 20.8$ & 280 & 80 & 170 & 5.38 & 73.9 & 27.7 & 48 \\
\hline \multirow[t]{2}{*}{3} & Prostatic & & & & & & & & \\
\hline & carcinoma & $26.0 / 17.6$ & 78 & 160 & 100 & 39.5 & 141 & 36.3 & 63 \\
\hline \multirow[t]{2}{*}{4} & Pancreatic & & & & & & & & \\
\hline & Carcinoma & ND & 80 & ND & 74 & 14.8 & 84.8 & 38.2 & 67 \\
\hline 5 & APL & $14.8 / 12.6$ & 160 & $>80$ & 22 & ND & 82.3 & 42.8 & 75 \\
\hline 6 & APL & ND & 90 & ND & 28 & 48.4 & 177 & 27.9 & 49 \\
\hline 7 & APL & $22.6 / 20.7$ & 120 & 40 & 2 & 12.9 & 134 & 57.5 & 101 \\
\hline 8 & APL & $18.0 / 19.9$ & 80 & 160 & 48 & 32.6 & 121 & 68.4 & 119 \\
\hline \multirow[t]{2}{*}{9} & Kasabach-Merritt & & & & & & & & \\
\hline & Syndrome & $21.7 / 20.0$ & 75 & 20 & 115 & 3.64 & 31.8 & 45.3 & 79 \\
\hline \multicolumn{2}{|c|}{ Normal range } & & $170-410$ & $<10$ & $150-350$ & $0.33-2.0$ & $3.79-13.2$ & & $70-130$ \\
\hline
\end{tabular}

Each of the above results for the thrombin time represents the value for the individual patient plasma over that for the control plasma in seconds. ND indicates that the test was not done. 
Table III. The Levels of PCP in Patients on Oral Anticoagulant Therapy

\begin{tabular}{lllll}
\hline $\begin{array}{l}\text { Patient } \\
\text { no. }\end{array}$ & $\begin{array}{l}\text { Prothrombin } \\
\text { time }\end{array}$ & PCP & Protein C & \\
\hline & & $p M$ & $n M$ & \% normal \\
1 & $26.6 / 11.5$ & 2.84 & 38.9 & 68 \\
2 & $22.0 / 11.3$ & 3.27 & 28.6 & 50 \\
3 & $51.0 / 11.3$ & 1.74 & 16.9 & 30 \\
4 & $17.0 / 11.5$ & 3.38 & 34.7 & 61 \\
5 & $20.0 / 11.5$ & 3.66 & 23.6 & 41 \\
6 & $25.0 / 11.5$ & 0.76 & 29.8 & 52 \\
7 & $28.5 / 11.5$ & 2.60 & 39.0 & 68 \\
Normal range & $3.79-13.2$ & & $70-130$ \\
\end{tabular}

Each of the above results for the prothrombin time represents the value for the individual patient plasma over that for the control plasma in seconds.

To reliably estimate the levels of activated protein $\mathrm{C}$ in the human circulation with the PCP RIA procedure, it is necessary to know the relative rates of clearance of the peptide vis a vis the enzyme. The clearance of both native and synthetic PCP have been studied in primates (Macaca fascicularis) at the New England Regional Primate Research Center. To this end, either the native or synthetic peptide was infused as a bolus into a peripheral arm vein. Blood was drawn through a catheter placed in the femoral vein into preloaded syringes containing PCP anticoagulant. Samples were obtained at various time points and assayed for PCP immunoreactivity. The $t_{1 / 2}$ in two animals infused with a total of 3.55 or $0.272 \mathrm{nmol}$ of native peptide were 5.25 and $4.50 \mathrm{~min}$, respectively (Fig. 4). Similar results were obtained with the synthetic analogue in a third animal (data not shown). We calculate that $\sim 50 \%$ of the infused peptide was recoverable in the monkey's plasma at time zero. Given that the $t_{1 / 2}$ of activated protein $C$ has previously been reported to average 10 to $15 \mathrm{~min}(33)$, the levels of enzyme in the circulation are likely to be two- and threefold that of the peptide concentration.

\section{Discussion}

The importance of protein $\mathrm{C}$ as a regulator of hemostatic system activity has been substantiated by the identification of several families with an inherited deficiency of this zymogen that is associated with a thrombotic diathesis (34-36). It seems likely that additional defects in the protein C-thrombomodulin mechanism such as decreased ability of thrombin to complex with this endothelial cell receptor, diminished density of thrombomodulin sites within the microvasculature, or reduced capacity of the bound serine protease to generate activated protein $\mathrm{C}$ may also be involved in congenital or acquired thrombotic disorders. Therefore, it is important to develop methods for quantitating abnormally low levels of protein $\mathrm{C}$

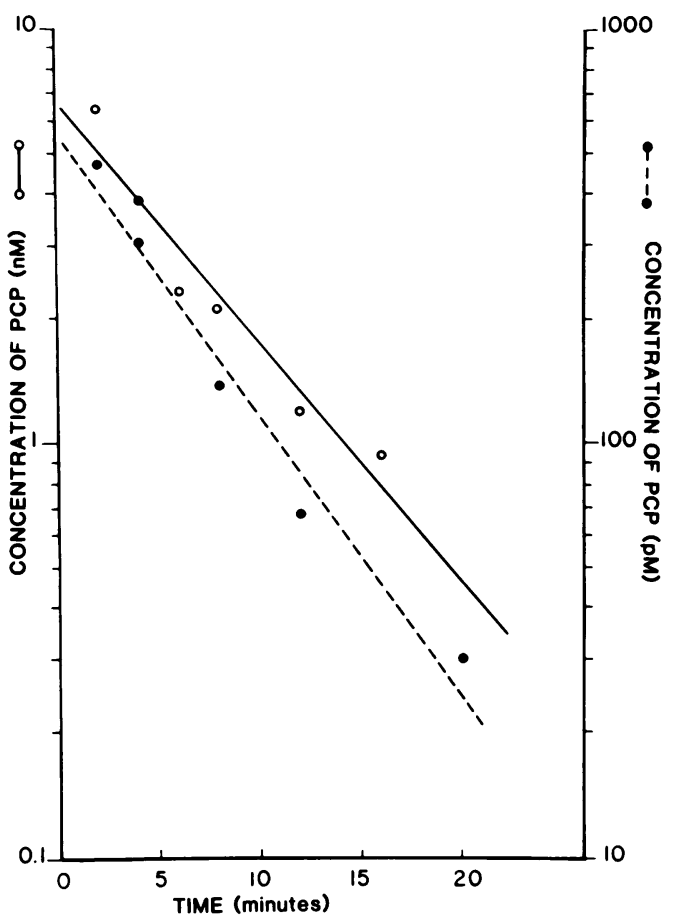

Figure 4. PCP levels in the plasma of primates infused with native peptide. The levels of peptide were measured by RIA. The $t_{1 / 2}$ were $5.25(0)$ and $4.50 \mathrm{~min}(\bullet)$ in studies performed on two separate animals.

activation within the vascular tree. However, the concentrations of coagulation system zymogens under in vivo conditions are controlled by synthetic and catabolic pathways rather than by conversion of these components to the corresponding serine proteases. Indeed, Majerus et al. (37) have calculated that only $1-2 \%$ activation of the normal plasma levels of protein $\mathrm{C}$ could account for the destruction of a substantial amount of Factor Va. The measurement of protein $\mathrm{C}$ concentration would not thus reveal the extent of activation of this protein within the plasma of patients with various pathologic disorders. Given the low levels of protein $\mathrm{C}$ conversion that must be detected under in vivo conditions, we have directed our attention to the immunochemical quantitation of the dodecapeptide that is liberated in conjunction with the generation of activated protein $\mathrm{C}$. Our laboratory has successfully used a similar approach to study prothrombin activation within the vascular system by developing a RIA for the prothrombin activation fragment $F_{1+2}(22,30)$.

To this end, antisera directed against the synthetic analogue of PCP were raised in rabbits. The antibody populations obtained were used to construct a double antibody RIA. We have established that the synthetic peptide has the same immunoreactivity as the native component produced by complete in vitro activation of protein $\mathrm{C}$. Furthermore, within our assay the reactivity of the protein $C$ zymogen is $<1 / 2,000$ that of the activation peptide on a molar basis. 
Unfortunately, our initial investigations also revealed that the normal plasma levels of dodecapeptide were below the detection limit of the PCP RIA. Furthermore, other components of the blood were observed to interfere in a nonspecific fashion with the reliable determination of the concentration of this peptide. Thus, it was necessary to devise a procedure by which the PCP could be extracted from plasma and concentrated $\sim 20$-fold before measurement of the levels of dodecapeptide. This was accomplished by precipitating plasma proteins with perchloric acid, and concentrating the dodecapeptide within the supernatant fraction with SEP-PAK $\mathrm{C}_{18}$ cartridges. This method allowed us to reproducibly recover between 50 and $70 \%$ of the PCP signal from plasma and to demonstrate that normal levels of this peptide averaged $\sim 6.5 \mathrm{pM}$. The plasma levels of PCP were found to be markedly elevated in patients with DIC ranging from 5- to 27-fold above their normal mean concentration. The validity of these measurements of protein $\mathrm{C}$ activation in normal individuals as well as those with excessive hemostatic system activity is supported by our demonstration that, in both of these situations, nearly $80 \%$ of the plasma RIA signal migrates on reverse-phase HPLC in a manner identical to that of the native dodecapeptide.

To utilize PCP levels in estimating the plasma concentration of activated protein $C$, it was essential to determine the clearance of dodecapeptide within the circulatory system and compare it to that of the enzyme. To this end, either native or synthetic peptide were infused into the peripheral veins of primates and the clearance rates of these components was determined. The $t_{1 / 2}$ for both types of PCP averaged $\sim 5 \mathrm{~min}$. This value is similar to that obtained for fibrinopeptide $A$ (FPA) in humans (21). The latter species exhibits a molecular weight similar to that of PCP. Given that the $t_{1 / 2}$ of activated protein $C$ has been estimated to be $\sim 10$ to $15 \mathrm{~min}$ (33), the levels of enzyme in the circulation are likely to be two to threefold that of the concentration of peptide. We therefore estimate that the maximal amount of activated protein $C$ that can be generated in the systemic circulation of individuals with the DIC syndrome is $\sim 500 \mathrm{pM}$. This represents $<1 \%$ of the total normal zymogen concentration. This extent of activation is comparable to that which we have previously reported for prothrombin by quantitating the plasma levels of prothrombin fragment $F_{1+2}(30)$.

Other investigators have noted that patients with evidence of DIC exhibit significant reductions in the antigenic levels of plasma protein $C(2,38)$. Decreased plasma concentrations of the zymogen have also been associated with the postoperative state or with sepsis $(2,38)$. Based upon our data, it is clear that the generation of activated protein $C$ occurs to only a very limited extent in vivo and is highly correlated with thrombin activity as measured by the FPA assay. While protein $C$ levels were often decreased in individuals experiencing DIC, the degree of antigen reduction bore little relationship to the PCP concentration. The clearance rate of this zymogen has been estimated to be of the order of 6-8 h, which is similar to that of Factor VII (39). Thus, the decreased levels of protein $\mathrm{C}$ are probably attributable in large part to factors other than the conversion of the zymogen to the corresponding serine protease.

The highest PCP concentration we have observed to date (484 pM) occurred in a patient experiencing acute deep venous thrombosis. This suggests that maximal zymogen activation could occur in the setting of localized thrombotic disease. The protein C-thrombomodulin mechanism may thus exert its regulatory role by limiting the extent of thrombosis at sites of excessive thrombin generation. It will, therefore, be of interest to correlate peptide levels with objective clinical endpoints of thrombus extension such as ${ }^{125}$ I-fibrinogen leg scans and impedance plethysmography.

We have also shown that patients on warfarin anticoagulants exhibit a reduction of plasma PCP levels. This effect presumably arises due to diminished thrombin generation (32) with resultant suppression of protein $\mathrm{C}$ activation. Furthermore, a decrease in the plasma concentration of protein $\mathrm{C}$ and/or its gammacarboxyglutamic acid content, which occurs in patients ingesting warfarin $(34,40)$, probably contributes to this phenomenon. Therefore, the PCP RIA may have utility in documenting reduced levels of protein $C$ activation.

In conclusion, the development of the PCP RIA has allowed us to provide the first direct evidence that the protein $\mathrm{C}$ mechanism is normally active in humans. Marked elevations in the extent of protein $\mathrm{C}$ activation have been found in individuals with DIC, and significant reductions were noted in individuals on oral anticoagulants. Given the sensitivity of our methodology, it should be possible to utilize this approach to evaluate the in vivo function of the protein C-thrombomodulin mechanism in prethrombotic states.

\section{Acknowledgments}

This work was supported in part by grant 13-512-823 from the American Heart Association, Massachusetts Affiliate, Inc., and National Institutes of Health grants HL 28960, GM 26625, and RR00168 to the New England Regional Primate Research Center.

\section{References}

1. Kisiel, W. 1979. Human plasma protein C: Isolation, characterization, and mechanism of activation by alpha-thrombin. J. Clin. Invest. 64:761-769.

2. Griffin, J. H., D. F. Mosher, T. S. Zimmerman, and A. J. Kleiss. 1982. Protein C, an antithrombotic protein, is reduced in hospitalized patients with intravascular coagulation. Blood. 60:261-264.

3. Esmon, C. T., and W. G. Owen. 1981. Identification of an endothelial cell cofactor for thrombin-catalyzed activation of protein C. Proc. Natl. Acad. Sci. USA. 78:2249-2252.

4. Owen, W. G., and C. T. Esmon. 1981. Functional properties of an endothelial cell cofactor for thrombin-catalyzed activation of protein C. J. Biol. Chem. 256:5532-5535.

5. Esmon, N. L., W. G. Owen, and C. T. Esmon. 1982. Isolation 
of a membrane-bound cofactor for thrombin-catalyzed activation of protein C. J. Biol. Chem. 257:859-864.

6. Kisiel, W., W. M. Canfield, L. H. Ericsson, and E. W. Davie. 1977. Anticoagulant properties of bovine plasma protein C following activation by thrombin. Biochemistry. 16:5824-5831.

7. Vehar, G. A., and E. W. Davie. 1980. Preparation and properties of bovine factor VIII (antihemophilic factor). Biochemistry. 19:410416.

8. Comp, P. C., and C. T. Esmon. 1979. Activated protein C inhibits platelet prothrombin-converting activity. Blood. 54:1272-1281.

9. Pepper, D. S., and C. Prowse. 1977. Chromatography of human prothrombin complex on dextran sulfate agarose. Thromb. Res. 11:687692.

10. Rosenberg, J. S., D. L. Beeler, and R. D. Rosenberg. 1975. Activation of human prothrombin by purified human factor $\mathrm{V}$ and factor $\mathrm{Xa}$ in the presence of human antithrombin. J. Biol. Chem. 250:1607-1617.

11. Rosenberg, R. D., and P. S. Damus. 1976. AntithrombinHeparin Cofactor. Methods Enzymol. 45:653-669.

12. Davis, B. J. 1964. Disc Gel Electrophoresis II. Method and application to human serum proteins. Ann. N. Y. Acad. Sci. 121:404427.

13. Rosenberg, R. D., and D. F. Waugh. 1970. Bovine thrombin: Multiple molecular components. J. Biol. Chem. 245:5049-5056.

14. Laemmli, U. K. 1970. Cleavage of structural proteins during the assembly of the head of bacteriophage T4. Nature (Lond.). 227:680685.

15. Myrmel, K. H., R. L. Lundblad, and K. G. Mann. 1976. Characteristics of the association between prothrombin fragment 2 and alpha-thrombin. Biochemistry. 15:1767-1773.

16. Bjork, I., and B. Nordenman. 1976. Acceleration of the reaction between thrombin and antithrombin III by non-stoichiometric amounts of heparin. Eur. J. Biochem. 68:507-511.

17. Merrifield, R. B. 1969. Solid-phase peptide synthesis. $A d v$. Enzymol. Relat. Areas Mol. Biol. 32:221-296.

18. Hruby, V. J., F. Muscio, C. M. Groginsky, P. M. Gitu, and D. Saba. 1973. Solid-phase synthesis of [2-isoleucine, 4-leucine]oxytocin and [2-phenylalanine, 4-leucine]oxytocin and some of their pharmacological properties. J. Med. Chem. 16:624-629.

19. Schlatter, J. M., and R. H. Mazur. 1977. Hydrogenation in solid phase peptide synthesis. I. Removal of product from the resin. Tetrahedron Lett. 33:2851-2852.

20. Goodfriend, T., L. Levine, and G. D. Fasman. 1964. Antibodies to bradykinin and angiotensin: A use of carbodiimides in immunology. Science (Wash. DC). 144:1344-1346.

21. Nossel, H. L., I. Yudelman, R. E. Canfield, V. P. Butler, Jr., K. Spanondis, G. D. Wilner, and G. D. Qureshi. 1974. Measurement of fibrinopeptide A in human blood. J. Clin. Invest. 54:43-53.

22. Lau, H. K., J. S. Rosenberg, D. L. Beeler, and R. D. Rosenberg. 1979. The isolation and characterization of a specific antibody population directed against the prothrombin activation fragments $F_{2}$ and $F_{1+2}$. J. Biol. Chem. 254:8751-8761.

23. Lau, H. K., and R. D. Rosenberg. 1980. The isolation and characterization of a specific antibody population directed against the thrombin-antithrombin complex. J. Biol. Chem. 255:5885-5893.

24. Greenwood, F. C., W. M. Hunter, and J. S. Glover. 1963. The preparation of ${ }^{131} \mathrm{I}$-labelled human growth hormone of high specific radioactivity. Biochem. J. 89:114-123.

25. Owen, C. A., Jr., E. J. W. Bowie, and J. H. Thompson, Jr. 1975. The Diagnosis of Bleeding Disorders. Little, Brown and Co., Boston. 2nd edition.

26. Rodbard, D. 1974. Statistical quality control and routine data processing for radioimmunoassays and immunoradiometric assays. Clin. Chem. 20:1255-1270.

27. Rodbard, D., R. H. Lenox, H. L. Wray, and D. Ramseth. 1976. Statistical characterization of the random errors in the radioimmunoassay dose-response variable. Clin. Chem. 1976; 22:350-358.

28. Lewis, A. E. 1966. Biostatistics. Van Nostrand Reinhold Company, New York.

29. Plow, E. F., and T. S. Edgington. 1975. A cleavage-associated neoantigenic marker for a gamma chain site in the $\mathrm{NH}_{2}$-terminal aspect of the fibrinogen molecule. J. Biol. Chem. 250:3386-3392.

30. Teitel, J. M., K. A. Bauer, H. K. Lau, and R. D. Rosenberg. 1982. Studies of the prothrombin activation pathway utilizing radioimmunoassays for the $F_{2} / F_{1+2}$ fragment and thrombin-antithrombin complex. Blood. 59:1086-1097.

31. Merskey, C., A. J. Johnson, G. J. Kleiner, and H. Wohl. 1967. The defibrination syndrome: Clinical features and laboratory diagnosis. Br. J. Haematol. 13:528-549.

32. Bauer, K. A., M. M. Bern, and R. D. Rosenberg. 1981. The suppression of prothrombin activation by warfarin in vivo. Blood. 58:229a. (Abstr.)

33. Comp, P. C., R. M. Jacocks, G. L. Ferrell, and C. T. Esmon. 1982. Activation of protein C in vivo. J. Clin. Invest. 70:127-134.

34. Griffin, J. H., B. Evatt, T. S. Zimmerman, A. J. Kleiss, and C. Wideman. 1981. Deficiency of protein $\mathrm{C}$ in congenital thrombotic disease. J. Clin. Invest. 68:1370-1373.

35. Broekmans, A. W., J. J. Veltkamp, and R. M. Bertina. 1983. Congenital protein $\mathrm{C}$ deficiency and venous thromboembolism: A study of three Dutch families. N. Engl. J. Med. 309:340-344.

36. Seligsohn, U., A. Berger, M. Abend, L. Rubin, D. Attias, A. Zivelin, and S. I. Rapaport. 1984. Homozygous protein C deficiency manifested by massive venous thrombosis in the newborn. $N$. Engl. J. Med. 310:559-562.

37. Salem, H. H., G. J. Broze, J. P. Miletich, and P. W. Majerus. 1983. Human coagulation factor $\mathrm{Va}$ is a cofactor for the activation of protein C. Proc. Natl. Acad. Sci. USA. 80:1584-1588.

38. Mannucci, P. M., and S. Vigano. 1982. Deficiencies of protein $C$, an inhibitor of blood coagulation. Lancet. 2:463-466.

39. S. Vigano, P. M. Mannucci, S. Solinas, B. Bottasso, and G. Mariani. 1984. Decrease in protein $C$ antigen and formation of an abnormal protein soon after starting oral anticoagulant therapy. $B r . J$. Haematol. 57:213-220.

40. Bertina, R. M., A. W. Broekmans, I. K. van der Linden, and K. Mertens. 1982. Protein C deficiency in a Dutch family with thrombotic disease. Thromb. Haemostas. 45:237-241. 